\title{
Tensions between 'consumerism' in elderly care and the social rights of family carers: a German- Danish comparison
}

\author{
Birgit Pfau-Effinger \\ Institut für Soziologie \\ University of Hamburg \\ Email: pfau-effinger@wiso.uni-hamburg.de
}

\section{Per H. Jensen}

Centre for Comparative Welfare Studies

Aalborg University

Email: perh@epa.aau.dk

\author{
Ralf Och \\ Institut für Soziologie \\ University of Hamburg \\ Email: ralf.och@uni-hamburg.de
}

\begin{abstract}
The focus of this article is on the effects of the strengthening of economic principles in the field of care that have taken place in many European welfare states since the 1990s, which are connected with new emphases on 'choice', on the role of the market in the provision of elderly care, and on efficiency as a new main welfare value. As a central part of this development, the figure of the elderly person in need of care, who was interpreted before these changes as the client or patient, has been replaced by the figure of a 'consumer' who makes 'free choices'. In most countries the frail elderly can choose between offers by different providers of home care who compete on the care market and care performed by family members. The focus of this article is on the legal construction of the working conditions of the family care giver. It aims to give an answer to two different research questions: How do different welfare states legally construct the working conditions of caring family members and their relationship with the elderly 'care consumers'? And to what degree does this cause tensions between the desire to care or not to care and actual care conditions and opportunities? In order to answer these questions, we compared the
\end{abstract}


legal construction of the work situation of family care givers in Germany and Denmark, as well as the resulting effects on their relationship with the older relatives who receive care. The findings show that the degree to which 'consumerism' in long-term care causes tensions in the situation of the caring family member and in the care relationship depends on the ways in which it is embedded in a family-care regime. In this regard, the tensions are clearly greater in the semi-formal familycare regime of Germany compared to the formal family-care regime in Denmark.

Keywords: consumerism, elderly care, social rights, family, Germany, Denmark

\section{Introduction}

The way social care is organized is crucial for the structuring of work in European welfare states. As a reaction to such changes as the ageing of society and the increase in women's labour-force participation rates, many welfare states in Europe have extended financial support and public provision in the field of childcare and elderly care since the 1990s, and have introduced new social rights both for care recipients and for those who provide care in the family (Anttonen \& Sipilä, 2005; Kröger \& Sipilä, 2005). At the same time, a restructuring of policies towards elderly care has taken place. These were based on a fundamental shift towards the strengthening of economic principles and on new emphases on 'choice' and the role of the market in the provision of care for older people and on efficiency as a new main welfare value. Accordingly, the introduction of new welfare markets in which non-profit and market-based providers compete together with new elements of public management and new Fordist principles in professional care work have been the main elements of the restructuring process (Bode, 2007; Daly, 2002; Knijn \& Verhagen, 2007; Rostgaard, 2006; Vabø, 2006; Pavolini \& Ranci, 2008).

As a central part of this development, the figure of the old person in need of care, construed before these changes as a client or patient, has been replaced by the 'consumer' who makes 'free choices' (Rostgaard, 2006; Ungerson, 2004; Vabø, 2006). Older people who need care should now be able to choose between different offers. In most countries these include offers of different types of providers of home care who compete on the care market public, for-profit, and non-profit providers. Family members are also included In part in the market competition, since the elderly person in need of care can also chose paid family care instead of home care in many programmes for long-term care in European welfare states (Ungerson, 2004). The introduction of these new policies towards care has in part created substantial new tensions and contradictions in the care arrangements in European welfare states, because the new principles of care provision contradict in part other principles like the need for a high quality of care. Germany provides a good example. Care work done by agencies on the basis of competition, as is allowed by the 'Long-Term Care Insurance Act', is strongly standardized and restricted to physical care activities, with the consequence that it often does not match the socially constructed expectations of care recipients and their relatives (Eichler \& Pfau-Effinger, 2009). 
This article aims to answer two different research questions. First, how do different welfare states legally frame the work conditions of caring family members and their relationship with the elderly 'care consumers'? Secondly, to what degree does this cause tensions between a desire to care or not to care and actual care conditions and opportunities? In order to answer these questions, we compared the legal framing of the work situation of family care givers in Germany and Denmark, as well as the resulting effects on their relationships with the older relatives who receive care.

We used for this objective the approach of different 'family-care regimes', by which we mean the ways the institutions of the welfare state legally construct the work situation of the person who provides care for an older relative and the care relationship between care giver and care receiver. We assumed that the differences in the legal construction of the work situation of the family carer, the care relationship, and the social rights connected with family care all differ in different types of welfare states. We present a comparative analysis of the legal framework regulating the family-based care of senior citizens in the welfare states of Germany and Denmark. Both welfare states have distinctly different cultural and institutional traditions in relation to care for old people. In Germany, for a long time and up to the mid-1990s, the family mainly provided elderly care, which was unpaid and not defined as 'work' (Pfau-Effinger, Jensen \& Flaquer, 2009). The Danish welfare state, in contrast, has had a longer tradition of state responsibility for the care of old people. Since the 1990s, these two different types of welfare states have further developed in regard to the ways in which they organize long-term care for older people. On the one hand, the sector of social services engaged in the care of old people has been extended in both societies. On the other hand, in both societies the field of care for old people has seen a strengthening of economic principles (Pfau-Effinger et al., 2009). Our analysis is an outcome of two research projects, one on Germany and the other on Denmark, led by the authors and funded by the German Research Council (DFG) and the Danish Research Council for the Social Sciences.

\section{Discussion of the State of the Art}

Most scholars would probably agree that care needs are increasing with the ageing of populations, and that change in the roles of care and care relationships is associated with changing institutions, cultures, policies, and processes. However, while some scholars employ a biographical approach for analysing the conditions of the 'biographical continuity' of care givers in the face of life-changing challenges (e.g., Chamberlayne \& King, 2000), this study employs a state-centred or citizenship perspective; that is, we are interested in how welfare policies (and citizens' rights) rather than biographical resources structure the organization of care. This article has as its starting point in the fact that many welfare states have introduced long-term care programmes based on allowances which give older people in need of care the choice of either hiring a paid care giver from the marketplace or paying caring family members. The idea is that older people in need of care can act as autonomous, self-reliant social citizens who have the 'freedom of choice' between different offers, which is epitomized as a right to receive care. Furthermore, these programmes also include new social rights from the point of view of the family care giver (see Knijn \& Kremer, 1997). These include their right to receive some kind of pay for the care they provide, a social right to time off for care tasks (i.e., an exemption from the obligation to work), and in part elements of social security for the duration they provide long-term care (Pfau-Effinger, 2005). 
These new policies of 'freedom of choice' represent ideas of consumerism, especially on the part on the person in need of care, as consumerism is based on 'access, choice, information, redress and representation' (Vabø, 2006:405). Whereas other concepts like empowerment, user-orientation or userinvolvement treat the relationship between the person in need of care and the care provider as a trust relationship, this relationship of consumerism is one based on material interest and is mediated via the market. This means that the care receiver is viewed as an autonomous market participant who acts 'with scepticism and distrust towards the provider, [is] always ready to take action if services fail, [is] always looking for the best buy ("value for money")' (Vabø, 2006:405, 413).

Consumerism in elderly care has been a common trend in European countries since the 1990s. Various factors have been identified in the literature to explain this common trend, such as the incapacity of the traditional welfare state to meet individuals' needs and the trend towards marketization. In part, governments have justified the introduction of cash-for-care programmes with the need to empower those in need of care. Another reason is the trend towards the recognition of (formerly unpaid or cheaper) informal care work (Ungerson, 2005).

Thus far, little research exists about the consequences of consumerism on the ways in which the work relationship of the caring family member with the old person in need of care is legally constructed in different types of welfare states in a comparative perspective. Da Roit and Le Bihan (2011) have investigated the situation of women in cash-for-care arrangements of longterm elderly care in France and Italy. They were particularly interested in the ways these programmes shape informal care and family relations in these countries. They have analysed the situation of family care givers, mainly women, who combined employment and long-term care of an elderly family member, and have found that cash-for-care systems, differently from what is sometimes expected, do not in principle support a reintroduction of the family into care in these countries. Instead, people use them for outsourcing longterm care. However, unlike this present article, the main perspective of their study was on the work-family balance of caring women and less on the legal framework of family care.

Claire Ungerson (2004) has also conducted international comparative research into the ways that wages for the care work of caring family members are constructed. She has analysed how the 'commodification of care' has developed in five European countries: France, Great Britain, Italy, the Netherlands, and Austria. Her main focus is on the pay that caring family members receive and on how it is paid. She found that in several welfare states these payments have the character of what she calls 'routed wages', that is, 'the method whereby people in need of care are given cash rather than (or in addition to) formal care services, and then encouraged to employ their own care labour directly with this cash' (Ungerson, 2005:49). Ungerson, moreover, shows that the labour-market impact of the welfare-state policies towards work in long-term care is to some extent dependent on the funding regime of the specific welfare state. These regimes represent different combinations of the degree of regulation, on the one hand, and the degree of commodfication of care work, on the other. According to Ungerson, funding regimes cover a spectrum between fully commodified informal care and care paid only by additional inflows into the household.

The results of the above-mentioned studies also show that long-term care provided by family members no longer fits the description of informal work. 
Often it is paid in the context of welfare-state programs, and includes elements of social security. For this reason, Pfau-Effinger (2005) has introduced the term 'semi-formal care' for these kinds of family care. Comparative policy analyses of the legal framework of paid family care, how it constructs the work situation of those who provide care for elderly relatives, and their relationship with the elderly 'care consumer' have hitherto been relatively rare.

\section{The conceptual approach of this article}

We assumed that the family-care regimes in the welfare states of Germany and Denmark differ substantially, and therefore that the degree and nature of tensions which are connected with the care provided by family members for their frail elderly relatives also differ. By 'family members' we mean persons who belong by definition broadly to the same family as the persons in need of care, such as daughters and sons, spouses or partners. The indicators that we used to compare different family-care regimes in the field of long-term care include:

- the quality and degree of the elderly's social right to receive care provided or organized and co-financed by the welfare state and how these relate to their 'consumer' role;

- the quality and degree of the family members' legal rights connected with their care work in comparison with standard employment, such as:

- the duration and amount of pay, as well as conditions of eligibility for pay;

- the level of social-security rights to benefits for unemployment, pensions, sickness of caring persons;

- the right to leave regular employment or to reduce the working time in employment, and the degree to which the job is protected in this situation;

- the legal rights within the care relationship (e.g., protection against dismissal, etc.).

We shall analyse tensions that may be associated with the situation of the options that frail senior citizens have as 'consumers' of long-term care to 'choose', on the one hand, and the working conditions of caring relatives in the same legal context, on the other.

\section{Main features of welfare-state policies towards long-term care in the context of the German Care Insurance Act (SGB XI)}

Until the early 1990s, the care of elderly people in the former West German state had essentially been organized as unpaid family care, and for this reason the classification of the German welfare state in this respect as a 'conservative welfare regime' in Esping-Andersen (1999) and its description as a 'political regime strongly oriented towards the male breadwinner' in Lewis and Ostner (1994) were fully accurate. Care in residential homes played a secondary role by comparison (Alber \& Schölkopf, 1999). In the former East German state, elderly care was also mainly based on unpaid family care 
despite the orientation towards a dual-earner family model (Heusinger \& Klünder 2005: 69; Naegele \& Dallinger 1993: 308).

With the 'Long-Term Care Insurance Act' implemented in 1995 and 1996, the German welfare state for the first time defined care for senior citizens as a task for the central state, and established a new social insurance that finances a universal basic provision for those in need of care on the basis of contributions from everyone in gainful employment. An important goal of this act was to make it possible for elderly people in need of care to live a selfdetermined life in a private household. The Long-Term Care Insurance Act (SGB XI) also introduced such elements as the market and 'consumer choice' into the organization of care. Further, on the basis of the financing of ambulant professional care by the long-term care insurance fund, the act encouraged the emergence of a broad sector of publicly financed providers in the field of ambulant care (Schulz-Nieswandt, Mann \& Sauer, 2010).

On the basis of these changes in the institutional framework of care, the autonomy of those in need of care has tended to be strengthened, since elderly people can release themselves from relationships of dependence on family care through opting for ambulant professional care. Nevertheless, in the largest proportion of cases family members exclusively still carry out the care of frail elderly people who live in private households. Among those people in old age who receive care allowance in the context of the Long-Term Care Insurance, 69.3 per cent live in their own household. In this group, the percentage of those who were cared for exclusively by a family member was 67 per cent in 2009 (Eichler \& Pfau-Effinger, 2009; Motel-Klingebiel, 2002; Mischke \& Meyer, 2008; Statistisches Bundesamt, 2009).

\section{The role of the consumer principle and 'free choice' for old people in the German policies towards long-term care}

Old people only have the right to receive paid care if they can prove that they have a physical need for it through illness or disability (§ 14 Abs. 1 SGB XI). Those who meet the rather tight selection criteria receive a care allowance that mainly covers only actual physical health care, and as long as they are not very seriously ill. They must themselves organize other items such as housework. Most recipients are thus still dependent on the additional support of family members if they want to live in their own households.

Old people who need care can choose between various providers of care: service agencies run by local authorities or non-profit organizations, as well as commercial providers. They also can claim care from family members such as spouses, partners, daughters and sons, and social networks. All these types of care are publicly paid to a certain degree. The care insurance makes the payment of the care allowance to the service agency if the care receiver has opted for care by an agency. The amount that the care insurance pays differs according to which of the three 'care levels' the person in need of care has been assigned to, that is, according to the extent of that person's requirements. If a person in need of care opts for an ambulant care service, the long-term care insurance fund pays a lump sum to the care service. This sum should cover a particular period of time for care per day. A lump sum of

\footnotetext{
${ }^{1}$ Elderly people who need care can also receive it from people outside the family, like neighbours or members of social networks, if these persons are willing to accept the conditions of care work done by family members. Currently, the share of persons belonging to such groups who provide care in this legal framework is relatively small (Statistisches Bundesamt 2009).
} 
$€ 420$ (care level 1), $€ 980$ (care level 2) or $€ 1,470$ (care level 3 ) is guaranteed per month (Deutscher Bundestag, 2008 SGB XI).

However, if a family member provides the care, the care allowance is considerably lower, and it is not paid directly to the family care giver but to the person in need of care. This constitutes a system of 'routed wages' (Ungerson, 2005 ). Payments to family members involved in care are from $€ 225$ per month (care level 1 ) to $€ 430$ per month (care level 2 ) and $€ 685$ per month (care level 3) (§ 37 Abs.1 SGB XI). ${ }^{2}$ Also, the elderly person who receives care has the freedom to decide to forward parts or all of these funds to the caring relative, or not at all.

The decision on agency care or family care - but not the choice of a specific family member - is binding for the person in need of care for a period of six months. This means that the person who receives care can dissolve at any time the care relationship with the relative. If a family member is providing care, an official inspection of the care situation and the person providing the care takes place once the care period starts. This is the only time an inspection of the specific care situation in the family takes place.

\section{The construction of the role of the caring family member in the German policies towards long-term care}

As we have mentioned above, caring family members can receive payment for their care work. This pay is defined as some 'financial 'compensation for effort' paid for certain categories of otherwise unpaid voluntary work (cf. PfauEffinger et al. 2009). This corresponds to a payment of between four and five Euros per hour for the average amount of time a caring family member spends on care. However, the caring relative does not have a legal right to payment for her or his care work. Instead, the care receiver is free to decide whether to keep the money or to forward it to the caring relative; there is no obligation to pay, and the way he or she uses is not monitored.

Family members who provide care at least 14 hours per week in the framework of the Care Insurance Law have the option to be included in the pension system for the periods in which they provide long-term care $(\S 19$ SGB XI). They are also covered by insurance against accidents at the workplace (§ 44 Abs. 1 Satz 4 SGB XI, Hervh). On the other hand, they have neither the right to be covered by public health insurance nor by unemployment insurance, even though the care relationship can end anytime when the care recipient moves into any kind of home, dies, or just decides on a different care giver. Even though the person in need of care is bound to the decision for family care or agency care for six months ( $\$ 38$ SGB XI), this does not mean that she or he is obliged to maintain the relationship with a specific person during this time.

Further, even though a family member who cares for an older relative who receives the care allowance enters into a legal relationship with the care recipient, the law explicitly mentions that caring family members do not have a position as 'employees', that their pay does not have the character of wages, and that their relationship with the care receiver who pays them does not have

\footnotetext{
${ }^{2}$ It is also possible for the person in need of care to transfer the benefits from the care insurance to a 'personal budget' account, from which he or she 'buys' care work ( $\$ 35$ a SGB XI). In practice, this solution is rather similar to the direct payments made by the care insurance.
} 
the character of an employment relationship (§ 3 S 2 SGB VI; Krauskopf Soziale Krankenversicherung, Pflegeversicherung, 71 Ergänzungslieferung 2010 Randnummer 4 zu § 19 SGB XI). The care relationship is also not based on any written contract. This means that family members who care for a frail older relative do not have any of the rights usually connected with an employment contract, like protection against unfair dismissal. They do have a right to four weeks' leave from the care situation in case they are sick or for holidays, but they do not receive pay for time off. During these four weeks, the Care Insurance pays for substitute care from another family member or a care agency ( $\$ 39$ SGB XI). The unpaid time for holidays of four weeks is reduced for each day the care giver is sick and cannot work. This means that only healthy family carers have the full right to four weeks' unpaid holidays.

Independent of SGB XI, there is a state programme for elderly-care leave from regular jobs in firms. People who temporarily care for an older family member can take unpaid care leave from the firm where they are normally employed. During this leave the worker's job is protected; dismissal is not possible. There are two different leave plans for persons who provide care for relatives: the 'care holiday' (Pflegeurlaub) and the 'caring time' (Pflegezeit). The 'care holiday' comprises a maximum of ten working days and can be paid time if this is permitted by collective bargaining agreements. The 'caring time' is unpaid and can last a maximum of six months. The option is limited to employees of firms with a size of more than 15 employees. During the leave the job is likewise protected ( $\S 5$ and $\S 7$ Pflegezeitgesetz). It is also possible for employed people to reduce their usual working hours over a longer period, maybe even over several years, if they have been employed at least six months in the firm, if the employer does not object for economic reasons, and if the firm has more than 15 employees ( $§ 11$ Teilzeit- und Befristungsgesetz). ${ }^{3}$

\section{Main features of welfare-state policies towards long-term care in Denmark}

Contrary to the case in Germany, where public long-term care was institutionalized as cash-for-care as soon as the welfare state started to take over the main responsibility for long-term care, public long-term care in Denmark has historically been delivered as a public in-kind service, in part as home care and in part as residential homes for older people in need of more extensive care. The coverage of in-kind care has grown constantly and rapidly (Finansministeriet, 1995:9) - already by 1996 about 30 per cent of the total population aged 65 and over was receiving some kind of long-term care (Regeringen, 1999) - and so have public expenditures (Strukturkommissionen, 2004). In effect, almost all older people in need of care are offered publicly financed and organized in-kind care provision.

Public in-kind care has become a citizen's right. The provision of in-kind services is regulated by the Social Service Law which stipulates that necessary services must be given in accordance with every individual recipient's need (cf. Jensen, Larsen \& Stoltenborg, 2004; Jensen \& Lolle, 2010; Rostgaard in this issue). To relieve the pressure on the public-care sector, from 1996 public authorities have offered prophylactic visits to people over 80 years, and from 1998 to those over 75. The aim of these advice and support measures is to enable older people to look after themselves better.

\footnotetext{
3 Teilzeit- und Befristungsgesetz vom 21. Dezember 2000 (BGBI. I S. 1966), last change by Artikel 1, 19. April 2007 (BGBI. I S. 538).
} 
In Denmark, family care by spouses and inter-generational family care and family carers has practically disappeared, which is in accordance with majority cultural orientations in Denmark. The vast majority of Danes have the opinion that frail elderly people should be taken care of by public in-kind care. The family has thus been emptied of elderly care functions (Christoffersen, 1997). This development does not mean, however, that children do not at all care for their frail elderly relatives. A time-use study conducted in 2001 shows that 40 per cent of all Danes had helped or eased the situation of their parents or parents-in-law within the last four weeks. Still, this sort of help remains optional. The welfare state first and foremost delivers personal help to frail elderly people.

The strengthening of economic principles in elderly care in the Danish welfare state has primarily taken the form of outsourcing public-care provision and of allowing clients to choose freely between different public and private providers of elderly care. Home care, and not residential care, has been subject to outsourcing, and outsourcing has not changed the content or quality of in-kind home care. Public authorities finance and define the quality of care provision, and the welfare state has remained the primary party responsible for ensuring the adequate offer of care. It is only the care providers who have changed with outsourcing. Thus the major aim of outsourcing has been to empower frail elderly people by giving them choices or exit-opportunities as 'consumers' of welfare-state provision. Only a relatively small proportion of old frail elderly, however, have actually chosen a private provider over a public provider of home care.

\section{The role of the consumer principle and 'free choice' for old people in need of care in the Danish policies towards long- term care}

Since January 1,2003 , recipients of home help have been free to choose from different providers of home care, both public and private. The advantages of choosing a private provider are that private providers are allowed to offer additional, non-care services such as gardening, walking the dog, and so forth. Becoming a for-profit private contractor, however, requires the certification of the company by the municipality, and to attain this certification the private contractor must provide the quality of services required by the municipality. There is, however, no real price competition in the care market. Private contractors receive the same amount from the municipalities as the municipality itself spends on home care. If a consumer of home care chooses a private contractor, then the municipality pays for the private services directly to the private contractor. This means that the users are not involved in any kind of economic transaction, except in cases where users have ordered additional services (such as dog-walking) from the private contractor. Such services are settled between the consumer and private contractor.

A 'softer' free-choice approach has been introduced in relation to residential care. Since July 1,2002 , elderly people who have been assigned a residence in a residential home can in principle choose from institutions within and across municipal borderlines. With this change, it is possible for older people to take up a residence that is more in accordance with their wishes. Previously, municipalities only assigned residences to 'their own' population. The idea underlying this change was that older people in need of care should be able to settle closer to the homes of their children or other relatives. 


\section{The construction of the role of the caring family member in the Danish policies towards long-term care}

Home care is delivered as personal assistance or care or as practical work in the home, in the form of cleaning, and so on, or both. These services, however, are to some extent dependent on the household situation of the elderly person in need of care. If the elderly person in need of care shares his or her household with a physically capable person, that person is expected to do all the practical work in the home; in other words, payment for home care in the form of housework is not granted.

With respect to personal assistance and care, relatives may themselves substitute for the public or private care provider. In such cases people who care for their frail elderly relatives do not enter into any legal relationship with the person in need of care, which would make them dependent on this person. Instead, they can choose public employment as carers with a 'normal' employment contract. The 'Law on Social Service' allows the person who is entitled to help and support to appoint a person to do the task (e.g. a spouse or a relative) (\$74). The municipality must, however, recognize the person appointed, and a contract that specifies the extent and content of services, security of delivery, costs, and so on, between the municipality and the appointed person must be made. In effect, the family care giver becomes a public employee. If the care receiver is granted, for example, seven hours home care per week, the municipality will employ the appointed person for seven hours per week at a wage rate of about 19 Euros per hour. Since those people who provide long-term care for their relatives in principle act as public employees, they are entitled to all types of social security and other legal rights of a standard employment relationship. This regulation is very rarely used, however.

Different from Germany, in Denmark there is no general state programme which gives family members who care for their frail older relatives the right to 'care leave' from their jobs. In Denmark, employees only have a right to unpaid care leave if they have to take care of a closely related dying, handicapped or seriously ill person. As far as people must take leave to care for a dying close relative, they are entitled to compensation amounting to 1.5 times sickness pay but not exceeding the wage that they have earned so far. In contrast, there are no legally based rights to absenteeism for 'ordinary' long-term care on a nearly daily basis.

\section{The legal framework of family care and its contradictions in the German and Danish care policies}

It has turned out that the legal framework of family care differs considerably between the German and the Danish welfare states (see also Table 1). These differences of legal framework regard the social rights of senior citizens as well as their role as 'consumers'. 
Table 1: Differences in the family-care regimes of the German and the Danish welfare state

\begin{tabular}{|c|l|l|}
\hline & German welfare state & Danish welfare state \\
\hline $\begin{array}{l}\text { Quality and degree of the elderly's social } \\
\text { right to receive care }\end{array}$ & medium & high \\
\hline $\begin{array}{l}\text { Quality and degree of the family } \\
\text { members' legal rights connected with } \\
\text { their work situation, in comparison with } \\
\text { standard employment }\end{array}$ & low to medium & high \\
\hline $\begin{array}{l}\text { Duration and amount of pay to } \\
\text { family carer, and conditions of } \\
\text { eligibility for pay; }\end{array}$ & $\begin{array}{l}\text { low to medium, clearly below } \\
\text { level of standard employment }\end{array}$ & $\begin{array}{l}\text { high - at level of standard } \\
\text { employment relationship }\end{array}$ \\
\hline $\begin{array}{l}\text { Level of social-security rights of } \\
\text { the family carer }\end{array}$ & low to medium, clearly below \\
level of standard employment \\
$\begin{array}{l}\text { Family carer's right to leave } \\
\text { regular employment or to reduce } \\
\text { the working time, and job } \\
\text { protection }\end{array}$ & medium & employment relationship \\
\hline $\begin{array}{l}\text { Legal rights of family carer } \\
\text { within the care relationship (e.g., } \\
\text { protection against dismissal, } \\
\text { etc.). }\end{array}$ & very low & $\begin{array}{l}\text { Low } \\
\text { magnitude of personal care } \\
\text { memployment relationship }\end{array}$ \\
\hline $\begin{array}{l}\text { The } \\
\text { performed by family members }\end{array}$ & high & very low \\
\hline
\end{tabular}

In Germany, the frail older person in need of care is considered a 'consumer' with 'free choice'. Therefore, senior citizens who need care have various rights and options. They can decide between different types of care, which includes the option to choose the care of a relative. If she or he decides that care should be given by a relative, the person receives funds to pay the care work of the relative, but does not have any obligation to forward the whole amount, or any part of it, to the caring family member. This means that in principle the person in need of care also has the option to use the funds as desired, say, to improve his or her own lifestyle. However, the financing of agency care carried out in private households mainly only covers physical health care. This limits considerably the social rights that senior citizens have in relation to long-term care. If they are not very seriously ill, they do not have the right to get payment for household help or overnight care. Care policies, therefore, rely considerably on family support of the old persons who want to live in their own households.

This is different in Denmark, where the conceptualization of old people who need care as 'consumers' is embedded in a different type of family-care regime. Old people in need of care usually get comprehensive care by public agencies. Different from Germany, public care for the individual person in need of care is also comprehensive. It includes 24-hour care if needed, and support in housework like cleaning and shopping. The consequence is that people in need of care are much less dependent on a caring relative's staying with them overnight and providing household work.

The differences in the legal framework of the caring family member are even greater. The other side of the relatively privileged situation of the care receiver 
in the German welfare state reveals that the situation of the care giver is relatively precarious. Care in the context of the SGB XI does not constitute an employment relationship, and does not even require any contract. It constitutes a relatively precarious, semi-formal form of care work paid in hourly wages clearly that is below market levels. The care giver does not even have a legal right to receive this pay. The social rights connected with the care situation of the family carer do include insurance against accidents and in part also pension insurance, but two fundamental social rights are absent, namely rights to health insurance and unemployment insurance. Free time off for sickness or holidays is guaranteed for up to four weeks but is unpaid, and it is possible for the care receiver to dissolve the care relationship at any time.

That the person in need of care can terminate the care relationship at any time means high income-loss risks particularly for those caring family members who may have given up or interrupted their regular jobs in the employment system in order to provide the family care. The care provider is, therefore, largely dependent on the good will of the person in need of care to maintain the care relationship and to receive the payments. Even if they do receive the full pay that the Care Insurance pays to the person in need of care, they may still be dependent on additional income sources, since the pay is below the poverty-line level. Given that family care, in 75 per cent of the cases, is provided by women, the law also contributes to maintaining gender inequality. The fact that family members who provide long-term care for a relative can take leave from their regular job which is then formally protected for the period, balances these risks to some degree. However, the leave is limited to six months.

The care policies of the German welfare state - the ways in which they construct the care situation of family care givers and their relationship to the person in need of care - therefore create particular tensions. The way the care relationship is legally framed causes distinctly contradictory interests within the family, that is, between the 'consumer' and the 'worker'. The care receiver, on the one hand, has the option of a free choice between different types of care and care providers, and can decide how she or he uses the 'care money' in the cases where the care is provided by a family member. The care giver who provides care for a family member, on the other hand, is legally in a relatively weak and precarious position. The affective nature of the relationship can reinforce this vulnerability. A main motive for why people care for older family members is love or the feeling of moral obligation (Eichler \& Pfau-Effinger, 2009).

The options of living autonomously in one's own household and of choosing between different types of care provision, including family care, are not at the expense of the family-care provider in the Danish welfare state. Family members can take over the daily care of a relative under an employment contract with the municipality and thereby act as a public employee, albeit on a (short) part-time basis. This means that they receive wages at levels commonly paid in the care sector, and have all the social rights and job protection of standard employment relationships. Differently from Germany, they do not have any legally constructed, direct financial relationship with the care receiver, and thus there is no personal or financial dependence of one or both partners on the care relationship.

On the other hand, again differently from Germany, an option for leave during which the job of the person who temporarily provides family care is guaranteed, does not exist. This may mean a substantial risk of job loss or difficulties returning to regular employment for an employee who decides to 
stay away for a longer time in order to care for an old relative in need of care. In this regard, the law creates a tension between the wish to take care of a family member temporarily, and the risk of losing one's regular job in doing so. As shown in Table 1, Denmark and Germany differ in all dimensions of the two family-care regimes. Other things being equal, the Danish situation is more favourable for the care recipient as well as for the family care giver as compared to the German situation. Paradoxically, however, the amount of family care giving is much greater in Germany than in Denmark.

\section{Conclusion}

It has turned out that the family-care regimes of Germany and Denmark differ considerably. On the one hand, a common trait of the welfare states of Germany and Denmark is that they construe old people in need of care as 'consumers' who have free choice in the care market. Frail elderly people have the option to decide between different types of care provided by agencies and between the care of agencies and family care, and they can get the funds to pay for the type of care they choose. This also means that people in need of care have the option to be 'freed' from personal dependence on the family. However, this option is more consistently supported in the Danish welfare state, since care provision is comprehensive and covers different types of needs of the person. In Germany, by contrast, care policies still rely on the care given by family members.

On the other hand, the family-care regimes of the German and the Danish welfare states are clearly different in the ways in which the situation of the person who provides family care is legally construed in her or his relationship to the relative receiving care. The care work of the person who provides family care in Germany is constructed as semi-formal care. It is based on poor pay, only some rights to social security, and little protection for the care giver in the care relationship. In this context, some main tensions are substantive to the care work and the care relationship between the relatives. Tensions exist between their wish to give the care and the financial and social insecurity and risks connected with the care situation. Moreover, the legal framework constructs tensions between the interests of the person who receives care and the person who provides care, and between the affective and the financial dimensions of the relationship between the care giver and care receiver.

In Denmark, the degree of tensions connected with the care situation of somebody giving temporary care to an older relative is clearly lower. Since family care is formalized, care during the daytime instead of working at their normal workplace is an option. In that case, the caring family member has an employment contract and receives wages that usually are paid for long-term care. Also, she or he has rights to social security and job protection as in any standard employment relationship. Caring, however, is associated with a loss of income, in as much as care is given only part-time, and the carer is forced to give up his or her ordinary full-time job. It follows from this disadvantage that there is tension caused for people who decide to take over the daily care of a family member, since they risk a loss of income as well as of their job itself because only a very restricted leave-taking scheme exists.

Our findings show that the degree to which 'consumerism' in long-term care is associated with tensions in relation to the care situation of the caring family member and the care relationship depends on the ways in which it is embedded into a family-care regime. In this regard, the tensions are clearly 
higher in the semi-formal family-care regime of Germany - compared to the formal family-care regime in Denmark.

\section{Acknowledgements}

We would like to thank Tine Rostgaard and the anonymous reviewer for their very helpful comments on an earlier version of this article.

\section{References}

Alber, J. \& Schölkopf, M. (1999), Seniorenpolitik: die soziale Lage älterer Menschen in Deutschland und Europa [Seniors policy: the social situation of older people in Germany and Europe], Amsterdam: Fakultas).

Anttonen, A., \& Sipilä, J. (2005). Comparative approaches to social care: diversity in care production modes. In B. Pfau-Effinger \& B. Geissler (Eds), Care Arrangements in Europe: Variations and Change (pp. 115-134). Bristol: Policy Press.

Bode, I. (2007). New moral economies of welfare: the case of domiciliary elder care in Germany, France and Britain. European Societies, 9(2), 201-227.

Chamberlayne, P. \& King, A. (2000). Cultures of care: biographies of carers in Britain and the two Germanies. Bristol: The Policy Press.

Christoffersen, M.N. (1997). Spædbarnsfamilien [Families with infants]. København: Socialforskningsinstituttet 97:25.

Daly, M. (2002). Care as a good for social policy. Journal of Social Policy. 31(2), 251270.

Dallinger, U. \& Naegele, G. (1993). Sozialpolitik und Lebenslage älterer Menschen in den neuen Ländern - Wandel im System sozialer Sicherung und Versorgung [Social policy and circumstances among the elderly in the new Länder: change in the system of social security and care]. In G. Naegele \& H.P. Tews (Eds). Lebenslagen im Strukturwandel des Alters. Alternde Gesellschaft Folgen für die Politik [Circumstances of structural change of ageing; an ageing society: consequences for policy]. Opladen: Westdeutscher Verlag.

Da Roit, B. \& Le Bihan, B. (2011). Tensions related to cash for care schemes. In B. Pfau-Effinger \& T. Rostgaard (Eds), Care between Work and Welfare in European Societies (forthcoming). Book Series of the Network of Excellence RECWOWE, London, Chicago: Palgrave.

Deutscher Bundestag (2007). Vierter Bericht über die Entwicklung der Pflegeversicherung [Fourth report on the development of long-term care insurance]. Berlin: Drucksache 16/7772.

Eichler, M. \& Pfau-Effinger, B. (2009). The 'consumer principle' in the care of elderly people - free choice and actual choice in the German welfare state. Social Policy and Administration, 43(6), 617-633.

Esping-Andersen, G. (1999). Social foundations of postindustrial economies, Oxford, 1999

Finansministeriet (1995). Budgetanalyse om hjemmehjælp [A budgetary analysis on home care]. København: Finansministeriet.

Heusinger, J., \& Klünder, M. (2005). "Ich lass' mir nicht die Butter vom Brot nehmen!". Aushandlungsprozesse in häuslichen Pflegearrangements ['I shall not allow the butter from my bread be taken': processes of negotiation in home-case arrangements]. Frankfurt am Main, Berlin: Mabuse-Verlag Wissenschaft. 
Jensen, P.H., Larsen, C.A. \& Stoltenborg, H.O. (2004). Ældre og ældrepolitik [The elderly and policy on the elderly]. In J. E. Larsen \& I. H. Møller (Eds), Socialpolitik. København: Munksgaard

Jensen, P.H. \& Lolle, H. (2010). Dynamics behind local variations in elderly care. Paper prepared for the 8th ESPAnet Conference, Budapest, 2-4 September 2010, Stream 12.2. Local Care Policies and Care Work in Times of Global Crisis

Jensen, P.H. \& Møberg, R. J. (2011). Tensions related to the transition of elderly care from an unpaid to a paid activity. In B. Pfau-Effinger \& T. Rostgaard (Eds), Care between Work and Welfare in European Societies (forthcoming). Book Series of the Network of Excellence RECWOWE, London, Chicago: Palgrave.

Knijn, T. \& Kremer, M. (1997). Gender and the caring dimension of welfare states. Toward inclusive citizenship. Social Politics, 4(3), 328-361.

Knijn, T. \& Verhagen, S. (2007). Contested professionalism. Payments for care and the quality of home care. Administration and Society, 39(4), 451-475.

Kröger, T. \& Sipilä, J. (Eds.), (2005). Overstretched: European Families Up Against the Demands of Work and Care. Malden: Blackwell.

Lewis, J. \& Ostner, I. (1994). Gender and the Evolution of European Social Policy. Working Paper 4 of the Centre for Social Policy Research, University of Bremen.

Mischke, C. \& Meyer, M. (2008).'Am Ende habe ich gewusst, was ich am Anfang gerne gewusst hätte' Beratung Pflegender Angehöriger Pflegeberatungsbedarfe im Verlauf von 'Pflegendenkarrieren' aus der Perspektive Pflegender Angehöriger, Projektabschlussbericht ["In the end I knew what I had wanted to know at the beginning": advice for care givers: Nursing requirements in the course of 'nursing-career' nurses from the perspective of family members.]. Saarbrücken: Hochschule für Technik und Wirtschaft des Saarlandes.

Motel-Klingebiel, A. (2002). Lebensqualität und Alter. Generationenbeziehungen und öffentliche Servicesysteme im sozialen Wandel [Life quality and age: generational relations and the public service system in a period of social change]. Opladen: Leske + Budrich.

North, D. C. (1992). Institutionen, institutioneller Wandel und Wirtschaftsleistung [Institutions, institutional change, and economic performance]. Übersetzt von Monika Streissler. Tübingen: Mohr.

Pavolini, E. \& Ranci, C. (2008). Restructuring the welfare state: reforms in long-term care in Western European countries. Journal of European Social Policy, 18(3), 246-259.

Pfau-Effinger, B. (2005). Welfare state policies and development of care arrangements. European Societies, 7(3), 321-347.

Pfau-Effinger, B., Jensen, P.H., \& Flaquer, L. (2009). Formal and informal work in European societies - A comparative perspective. In B. Pfau-Effinger, P.H. Jensen, \& L. Flaquer (Eds.) Formal and Informal Work in Europe. The Hidden Work Regime (pp. 193-213). London, New York: Routledge.

Regeringen (1999). Strukturovervågning: International benchmarking i Danmark. København: Finansministeriet

Rostgaard, T. (2006). Constructing the care consumer - free choice of home care for the elderly in Denmark. European Societies, 8(3), 443-463.

Schulz-Nieswandt, F., Mann, K., \& Sauer, M. (2010). Europäische Sozialpolitik und Europäisierung der Gesundheits- und Sozialdienstleistungen- ein Abriß [European social policy and the Europeanization of the health and social public services: a survey]. Sozialer Fortschritt, 59(5), 127-134. 
Statistisches Bundesamt (2009). Pflegestatistik 2009. Pflege im Rahmen der deutschen Pflegeversicherung-Deutschlandergebnisse [Statistics on care 2009: case in the conditions of the German long-term care insurance - the findings for Germany]. Wiesbaden: Statistisches Bundesamt.

Strukturkommissionen (2004). Strukturkommissionens betænkning - Bind III [Commission on the political and administrative structure, vol. III]. København: Indenrigs- og Sundhedsministeriet

Ungerson, C. (2004). Whose Empowerment and Independence? A cross-national perspective on 'cash for care' schemes. Ageing \& Society, 24(2), 189-212.

Vabø, M. (2006). Caring for people or caring for proxy consumers? European Societies, 8(3), 403-422. 